\title{
COVID-19 Among Workers in Meat and Poultry Processing Facilities - 19 States, April 2020
}

\begin{abstract}
Jonathan W. Dyal, MD ${ }^{1,2}$; Michael P. Grant, $\mathrm{ScD}^{1}$; Kendra Broadwater, $\mathrm{MPH}^{1}$; Adam Bjork, $\mathrm{PhD}^{1}$; Michelle A. Waltenburg, DVM ${ }^{1,2}$; John D. Gibbins, DVM ${ }^{1}$; Christa Hale, DVM ${ }^{1}$; Maggie Silver, $\mathrm{MPH}^{1}$; Marc Fischer, MD ${ }^{1}$; Jonathan Steinberg, MPH ${ }^{1,2,3}$; Colin A. Basler, DVM ${ }^{1}$; Jesica R. Jacobs, $\mathrm{PhD}^{1,4}$; Erin D. Kennedy, DVM ${ }^{1}$; Suzanne Tomasi, DVM ${ }^{1}$; Douglas Trout, MD ${ }^{1}$; Jennifer Hornsby-Myers, MS ${ }^{1}$;

Nadia L. Oussayef, JD ${ }^{1}$; Lisa J. Delaney, MS ${ }^{1}$; Ketki Patel, MD, PhD ${ }^{5}$; Varun Shetty, MD ${ }^{1,2,5}$; Kelly E. Kline, MPH ${ }^{6}$; Betsy Schroeder, DVM ${ }^{6}$; Rachel K. Herlihy, $\mathrm{MD}^{7}$; Jennifer House, $\mathrm{DVM}^{7}$; Rachel Jervis, $\mathrm{MPH}^{7}$; Joshua L. Clayton, $\mathrm{PhD}^{3}$; Dustin Ortbahn, $\mathrm{MPH}^{3}$;

Connie Austin, DVM, PhD ${ }^{8}$; Erica Berl, DVM 9 ; Zack Moore, MD 9 ; Bryan F. Buss, DVM ${ }^{10}, 11$; Derry Stover, $\mathrm{MPH}^{10}$; Ryan Westergaard, MD, PhD ${ }^{12}$; Ian Pray, PhD ${ }^{2,12}$; Meghan DeBolt, MPH ${ }^{13}$; Amy Person, MD ${ }^{14}$; Julie Gabel, DVM ${ }^{15}$; Theresa S. Kittle, MPH ${ }^{16}$; Pamela Hendren ${ }^{17}$;

Charles Rhea, $\mathrm{MPH}^{17}$; Caroline Holsinger, DrPH ${ }^{18}$; John Dunn ${ }^{19}$; George Turabelidze ${ }^{20}$; Farah S. Ahmed, PhD ${ }^{21}$; Siestke deFijter, MS ${ }^{22}$;

Caitlin S. Pedati, MD²3; Karyl Rattay, MD ${ }^{24}$; Erica E. Smith, PhD ${ }^{24}$; Carolina Luna-Pinto, MPH ${ }^{1}$; Laura A. Cooley, MD ${ }^{1}$; Sharon Saydah, PhD ${ }^{1}$; Nykiconia D. Preacely, DrPH ${ }^{1}$; Ryan A. Maddox, $\mathrm{PhD}^{1}$; Elizabeth Lundeen, $\mathrm{PhD}^{1}$; Bradley Goodwin, $\mathrm{PhD}^{1}$; Sandor E. Karpathy, PhD ${ }^{1}$; Sean Griffing, $\mathrm{PhD}^{1}$; Mary M. Jenkins, $\mathrm{PhD}^{1}$; Garry Lowry, $\mathrm{MPH}^{1}$; Rachel D. Schwarz, MPH${ }^{1}$; Jonathan Yoder, $\mathrm{MPH}^{1}$; Georgina Peacock, MD ${ }^{1}$; Henry T. Walke, MD ${ }^{1}$; Dale A. Rose, $\mathrm{PhD}^{1}$; Margaret A. Honein, $\mathrm{PhD}^{1}$
\end{abstract}

On May 1, 2020, this report was posted as an MMWR Early Release on the MMWR website (https://www.cdc.gov/mmwr). Congregate work and residential locations are at increased risk for infectious disease transmission including respiratory illness outbreaks. SARS-CoV-2, the virus that causes coronavirus disease 2019 (COVID-19), is primarily spread person to person through respiratory droplets. Nationwide, the meat and poultry processing industry, an essential component of the U.S. food infrastructure, employs approximately 500,000 persons, many of whom work in proximity to other workers (1). Because of reports of initial cases of COVID-19, in some meat processing facilities, states were asked to provide aggregated data concerning the number of meat and poultry processing facilities affected by COVID-19 and the number of workers with COVID-19 in these facilities, including COVID-19-related deaths. Qualitative data gathered by CDC during on-site and remote assessments were analyzed and summarized. During April 9-27, aggregate data on COVID-19 cases among 115 meat or poultry processing facilities in 19 states were reported to CDC. Among these facilities, COVID-19 was diagnosed in 4,913 (approximately $3 \%$ ) workers, and 20 COVID-19-related deaths were reported. Facility barriers to effective prevention and control of COVID19 included difficulty distancing workers at least 6 feet ( 2 meters) from one another (2) and in implementing COVID-19-specific disinfection guidelines.* Among workers, socioeconomic challenges might contribute to working while feeling ill, particularly if there are management practices such as bonuses that incentivize attendance. Methods to decrease transmission within the facility include worker symptom screening programs, policies

\footnotetext{
*https://www.cdc.gov/coronavirus/2019-ncov/community/disinfectingbuilding-facility.html.
}

to discourage working while experiencing symptoms compatible with COVID-19, and social distancing by workers. Source control measures (e.g., the use of cloth face covers) as well as increased disinfection of high-touch surfaces are also important means of preventing SARS-CoV-2 exposure. Mitigation efforts to reduce transmission in the community should also be considered. Many of these measures might also reduce asymptomatic and presymptomatic transmission (3). Implementation of these public health strategies will help protect workers from COVID-19 in this industry and assist in preserving the critical meat and poultry production infrastructure (4).

In early April, CDC was alerted to COVID-19 cases among workers in several meat and poultry processing facilities and responded to state and local authorities' requests for on-site or remote technical assistance. Qualitative on-site and remote risk assessments were conducted. All states that had reported at least one case of COVID-19 in a meat or poultry processing facility were contacted for further information. CDC requested aggregate data on the number of meat or poultry facilities affected, number of workers in affected facilities, number of workers with a COVID-19 diagnosis, and number of COVID-19-related deaths among workers. States reported COVID-19 among workers using their own case definitions.

By April 27, CDC had received aggregate data on COVID-19 cases from 19 of 23 states reporting at least one case related to this industry; there were 115 meat or poultry processing facilities with COVID-19 cases, including 4,913 workers with diagnosed COVID-19 (Table 1). Among 17 states reporting the number of workers in their affected facilities, $3.0 \%$ of 130,578 workers received diagnoses of COVID-19. The percentage of workers with diagnosed COVID-19 ranged 
from $0.6 \%$ to $18.2 \%$. Twenty COVID-19-related deaths were reported among workers.

Qualitative data from the facility risk assessments identified common characteristics among processing facilities and their workers that might increase risk for transmitting or acquiring SARS-CoV-2 (Table 2). Facility challenges included structural and operational practices that made it difficult to maintain a 6-foot (2-meter) distance while working, especially on production lines, and in nonproduction settings during breaks and while entering and exiting facilities. The pace and physical demands of processing work made adherence to face covering recommendations difficult, with some workers observed covering only their mouths and frequently readjusting their face coverings while working. Some sites were also observed to have difficulty adhering to the heightened cleaning and disinfection guidance recommended for all worksites to reduce SARS-CoV-2 transmission.

Solutions to structural and operational challenges that some facilities adopted included adjusting start and stop times of shifts and breaks to increase physical distance between workers. Outdoor break areas were added at some facilities to decrease contact between workers. Some facilities installed physical (e.g., plexiglass) barriers between workers; however, this was not practical for all worker functions. Symptom and temperature screening of workers was newly instituted in some facilities and improved in others.
Sociocultural and economic challenges to COVID-19 prevention in meat and poultry processing facilities (Table 2) include accommodating the needs of workers from diverse backgrounds who speak different primary languages; one facility reported a workforce with 40 primary languages. This necessitates innovative approaches to educating and training employees and supervisors on safety and health information. In addition, some employees were incentivized to work while ill as a result of medical leave and disability policies and attendance bonuses that could encourage working while experiencing symptoms. Finally, many workers live in crowded, multigenerational settings and sometimes share transportation to and from work, contributing to increased risk for transmission of COVID-19 outside the facility itself. Changing transportation to and from the facilities to increase the number of vehicles and reduce the number of passengers per vehicle helped maintain physical distancing in some facilities.

\section{Discussion}

Cases of COVID-19 have been observed in other congregate settings, including long-term care facilities (5), acute care hospitals (6), correctional facilities (7), and homeless shelters (8). Similarly, the crowded conditions for workers in meat and poultry processing facilities could result in high risk for SARS-CoV-2 transmission. Respiratory disease outbreaks in this type of setting demonstrate the need for heightened attention to worker safety (9). However, COVID-19 among

TABLE 1. COVID-19 among workers in meat and poultry processing plants - 19 states, April 2020*

\begin{tabular}{|c|c|c|c|c|c|}
\hline State & $\begin{array}{c}\text { Types of meat or poultry in } \\
\text { affected plants }\end{array}$ & $\begin{array}{l}\text { No. of plants } \\
\text { affected }\end{array}$ & $\begin{array}{l}\text { No. of workers in } \\
\text { affected plants }\end{array}$ & $\begin{array}{l}\text { No. }(\%) \text { of confirmed } \\
\text { COVID-19 cases } \\
\text { among workers }\end{array}$ & $\begin{array}{c}\text { No. }(\%)^{\dagger} \\
\text { COVID-19-related } \\
\text { deaths }\end{array}$ \\
\hline Colorado & Beef, bison, lamb, poultry & 5 & 7,248 & 139 (1.9) & $5(3.6)$ \\
\hline Delaware & Poultry & 6 & 9,411 & $336(3.6)$ & $4(1.2)$ \\
\hline Georgia & Poultry & 14 & 16,500 & $388(2.4)$ & $1(0.3)$ \\
\hline Illinois & Beef, pork, poultry & 5 & 6,680 & $112(1.7)$ & $1(0.9)$ \\
\hline lowa & Beef, pork & 2 & 2,075 & $377(18.2)$ & N/A \\
\hline Kansas & Beef, poultry, other & 6 & 16,600 & $106(0.6)$ & $0(0)$ \\
\hline Kentucky & Pork, poultry & 2 & 1,333 & 18 (1.4) & $1(5.6)$ \\
\hline Mississippi & Poultry & 9 & 9,548 & $123(1.3)$ & $0(0)$ \\
\hline Missouri & Beef, pork, poultry & 3 & 3,690 & $36(1.0)$ & $0(0)$ \\
\hline Nebraska & Beef, pork, poultry & 12 & 19,911 & $588(3.0)$ & $1(0.2)$ \\
\hline North Carolina & Pork, poultry & 5 & 14,600 & $166(1.1)$ & $0(0)$ \\
\hline Ohio & Pork & 1 & 710 & $10(1.4)$ & $0(0)$ \\
\hline Pennsylvania & $\mathrm{N} / \mathrm{A}$ & 22 & N/A & $858(-)$ & $1(0.1)$ \\
\hline South Dakota & Beef, pork & 2 & 4,600 & 794 (17.3) & $2(0.3)$ \\
\hline Tennessee & N/A & 3 & N/A & $132(-)$ & $0(0)$ \\
\hline Texas & Beef, poultry & 2 & 4,800 & $113(2.4)$ & $1(0.9)$ \\
\hline Virginia & Poultry & 10 & 7,072 & 128 (1.8) & $2(1.6)$ \\
\hline Washington & Beef & 1 & 1,400 & $100(7.1)$ & $1(1.0)$ \\
\hline Wisconsin & Beef, pork & 5 & 4,400 & 389 (8.8) & $0(0)$ \\
\hline Total & Beef, bison, lamb, pork, poultry, other & 115 & 130,578 & $4,913(3.0)^{\S}$ & $20(0.4)^{\Uparrow}$ \\
\hline
\end{tabular}

Abbreviations: COVID-19 = coronavirus disease 2019; N/A = not available.

* Data submitted during April 20-27, 2020.

† Percentage of deaths among cases.

$\S$ Excludes cases from Pennsylvania and Tennessee because number of workers (denominator) is not available from these states.

" Excludes cases from lowa in the denominator because information on number of deaths is not available from this state. 
Morbidity and Mortality Weekly Report

TABLE 2. Observed challenges and recommended changes in practice in response to COVID-19 among workers in meat and poultry processing facilities - selected states, ${ }^{*}$ April 2020

\begin{tabular}{|c|c|c|}
\hline Category & $\begin{array}{l}\text { Challenges to effective prevention and } \\
\text { control of COVID-19 }\end{array}$ & Recommended changes in facility practice $^{\dagger}$ \\
\hline \multirow[t]{3}{*}{ Structural } & $\begin{array}{l}\text { Maintaining physical distancing during breaks and when } \\
\text { employees enter and exit the facility }\end{array}$ & $\begin{array}{l}\text { Adjust start and stop times of breaks and shifts } \\
\text { Add outdoor breakrooms }\end{array}$ \\
\hline & Maintaining physical distancing on production line & Install physical barriers between workers \\
\hline & Excluding symptomatic workers & $\begin{array}{l}\text { Screen all workers and visitors entering facility and plan for effective isolation } \\
\text { for workers who become ill at work }\end{array}$ \\
\hline \multirow[t]{3}{*}{ Operational } & Maintaining physical distancing on production line & Reduce rate of animal processing \\
\hline & Adhering to face covering recommendations & $\begin{array}{l}\text { Require universal face covering } \\
\text { Ensure face coverings conformed to CDC guidance } \\
\text { Provide training on donning and doffing }\end{array}$ \\
\hline & $\begin{array}{l}\text { Adhering to heightened cleaning and } \\
\text { disinfection guidelines }\end{array}$ & $\begin{array}{l}\text { Assign additional staff to sanitize "high touch" areas (e.g., handles, buttons, } \\
\text { railings) more frequently } \\
\text { Add several hand sanitizer dispensers and handwashing stations } \\
\text { Implement touch-free time clocks }\end{array}$ \\
\hline \multirow[t]{3}{*}{ Sociocultural } & Communicating through language and cultural barriers & $\begin{array}{l}\text { Engage community partners to develop culturally informed messaging } \\
\text { Disseminate messaging in languages spoken among the work force }\end{array}$ \\
\hline & Employees live in crowded, multigenerational settings & $\begin{array}{l}\text { Include messaging about behaviors employees should take to limit the } \\
\text { spread of the virus while at home }\end{array}$ \\
\hline & Employees share transportation to and from work & $\begin{array}{l}\text { Add additional vehicles to shuttle routes } \\
\text { Require use of face coverings during commute }\end{array}$ \\
\hline Economic & Employees incentivized to work while ill & $\begin{array}{l}\text { Implement personnel policies that provide additional medical leave and } \\
\text { disability benefits without loss of seniority or pay } \\
\text { Remove financial incentives, such as attendance bonuses }\end{array}$ \\
\hline
\end{tabular}

Abbreviation: COVID-19 = coronavirus disease 2019.

* Based on CDC field team deployments to four sites and information gathered from calls with state health departments.

† Based on on-site and remote technical assistance, many facilities have implemented or are planning to implement these strategies.

workers in meat and processing facilities could be due to viral transmission at the workplace or in the community.

The food production industry is considered critical infrastructure, as described by the U.S. Department of Homeland Security, and its workers must be able to operate in an environment of enhanced safety. ${ }^{\dagger} \mathrm{CDC}$ has provided guidance for critical infrastructure workers. ${ }^{\S}$ For decisions about workers returning to work after an exposure or COVID-19, CDC suggests consultation with health care providers, occupational safety and health professionals, and state and local health departments. ${ }^{9}$ As testing becomes more widely available, consideration should be given to its role in rapidly identifying and addressing COVID-19 in this occupational setting. General interim recommendations for meat and poultry processing facilities will need to be interpreted and applied for each facility (4).

To shield workers from various hazards in meat and poultry processing facilities, the preferred approaches are to eliminate

\footnotetext{
${ }^{\dagger}$ https://www.cisa.gov/sites/default/files/publications/Version_3.0_CISA_ Guidance_on_Essential_Critical_Infrastructure_Workers_2.pdf.

$\S$ https://www.cdc.gov/coronavirus/2019-ncov/community/critical-workers/ implementing-safety-practices.html.

" https://www.cdc.gov/coronavirus/2019-ncov/hcp/disposition-in-homepatients.html.
}

a hazard or exposure source, install engineering controls, and implement effective sanitation and cleaning; enhanced administrative measures might also be needed. Employee and visitor screening procedures, such as temperature monitoring and symptom screening, are important to prevent introduction of COVID-19 into a facility from symptomatic persons. Whenever feasible, the workplace should be organized so that workers can be at least 6 feet ( 2 meters) apart. The nature of workplace modifications that might be needed to accomplish this will vary in each workplace; modifications might require changes in production practice, and feasibility will vary by workplace. Additional engineering options include stationing workers so that they are not facing each other and positioning fans so that they do not blow air from one worker directly onto another. Maintaining recommended hand hygiene requires access not only to handwashing stations, but also sufficient availability and use of alcohol-based hand sanitizer in areas where handwashing is not feasible.

Meat and poultry processing facilities typically employ extensive procedures for cleaning and sanitation as required by the U.S. Department of Agriculture for food safety. Surfaces should be thoroughly cleaned and then disinfected according 
to usual facility standard operating procedures. "High-touch" areas (e.g., handles, buttons, and railings) should be disinfected with products that meet Environmental Protection Agency criteria for use against SARS-CoV-2 and are approved under the facility's disinfection standard operating procedures.**

Administrative controls can support the infection control plan, including programs that actively encourage symptomatic workers to stay home. Personnel policies that allow the use of leave when ill without loss of seniority or pay can enable symptomatic workers to stay home. Similarly, avoidance of any incentives that might encourage workers to come to work while symptomatic can reduce risk in the workplace. Active symptom screening including temperature monitoring of all workers and visitors entering the facility can also reduce risk for COVID-19 introduction and transmission from symptomatic workers. Other important administrative controls to consider are plans for isolation of workers who become ill while at work and policies that promote social distancing and hand washing in all worksite settings.

To aid in source control, cloth face coverings are recommended by CDC in public settings to potentially help prevent transmission as a complement to social distancing. ${ }^{\dagger \dagger}$ Their use in facilities should be considered when distancing is not feasible but are not a replacement for adequate distancing (9). Face coverings should also be worn in nonproduction areas such as entrances, exits, break rooms, shared vehicles, and other areas in which maintenance of social distancing is challenging. Other factors, including potential for contamination and the need for replacement of face coverings, are also important to consider.

Use of personal protective equipment (PPE) in the usual operation of meat and poultry processing facilities is common to protect against hazards, and workers should continue using PPE required for their jobs. In the course of using PPE, facilities should emphasize correct donning and doffing of PPE to prevent contamination of the worker. PPE should be disposed of or properly disinfected and stored when not in use. Face shields are equipment that might serve as both PPE and source control in certain situations.

Periodic infection control and occupational safety and health training should be provided for all workers and supervisors tailored to literacy levels and preferred languages. Specifics of training should include, but are not limited to, what workers should do when they feel ill before or at work, symptoms of COVID-19, medical leave policies, social distancing recommendations,

\footnotetext{
**ht tps://www.epa.gov/pesticide-registration/ list-n-disinfectants-use-against-sars-cov- 2 .

†† https://www.cdc.gov/coronavirus/2019-ncov/prevent-getting-sick/diy-clothface-coverings.html.
}

\section{Summary}

What is already known about this topic?

Persons in congregate work and residential locations are at increased risk for transmission and acquisition of respiratory infections.

What is added by this report?

COVID-19 cases among U.S. workers in 115 meat and poultry processing facilities were reported by 19 states. Among approximately 130,000 workers at these facilities, 4,913 cases and 20 deaths occurred. Factors potentially affecting risk for infection include difficulties with workplace physical distancing and hygiene and crowded living and transportation conditions.

What are the implications for public health practice?

Improving physical distancing, hand hygiene, cleaning and disinfection, and medical leave policies, and providing educational materials in languages spoken by workers might help reduce COVID-19 in these settings and help preserve the function of this critical infrastructure industry.

correct donning and doffing of PPE and face coverings, hand hygiene practices, opportunities to access testing as it becomes more widely available, and potential routes of transmission at work and in the community. Training should be provided by culturally competent trainers, in a setting where social distancing can be maintained, in languages spoken by workers and with consideration given to varying levels of education.

The findings in this report are subject to at least four limitations. First, not all states with COVID-19 cases in meat and poultry facilities submitted data for this report. Second, differences in case counts and percentage of workers with COVID-19 are affected by the testing strategies employed, with more infected workers identified in settings with more testing. As a result, data provided on worker infections should not be interpreted as the prevalence of infection for all meat and poultry facility workers. Third, lag time in reporting to the local and state health departments also affects the counts reported, as does the time from disease onset to death in fatal cases. Finally, widespread community transmission in some settings makes determining the source of exposure and infection difficult.

As part of the national COVID-19 response, the recognized risk to meat and poultry facility operation requires prompt action to decrease risks to workers, preserve facility function, and maintain the food supply. Collaborative implementation of engineering controls, administrative controls, enhanced cleaning and disinfection, and source control in meat and poultry processing facilities might reduce COVID-19 among workers supporting this critical industry. 


\section{Acknowledgments}

State and local health departments in affected communities; affected facilities; Chas Debolt, Lisa Henry, Rick Hong, Scott Lindquist, Jamie Mack, Tabatha Offutt-Powell, Richard Pescatore, Shonetesha Quail, CDC COVID-19 Response Team.

Corresponding author: Jonathan Dyal,pgz7@cdc.gov.

${ }^{1}$ CDC COVID-19 Response Team; ${ }^{2}$ Epidemic Intelligence Service, CDC; ${ }^{3}$ South Dakota Department of Health; ${ }^{4}$ Laboratory Leadership Service, CDC;

${ }^{5}$ Texas Department of State Health Services; ${ }^{6}$ Pennsylvania Department of Health; ${ }^{7}$ Colorado Department of Public Health and Environment; ${ }^{8}$ Illinois Department of Public Health; ${ }^{9}$ North Carolina Department of Health and Human Services; ${ }^{10}$ Nebraska Department of Health and Human Services; ${ }^{11}$ Career Epidemiology Field Officer Program, CDC; ${ }^{12}$ Wisconsin Department of Health Services; ${ }^{13}$ Walla Walla County Department of Community Health, Walla Walla, Washington; ${ }^{14}$ Benton Franklin Health District, Kennewick, Washington; ${ }^{15}$ Georgia Department of Public Health; ${ }^{16}$ Mississippi State Department of Health; ${ }^{17}$ Kentucky Department for Public Health; ${ }^{18}$ Virginia Department of Health; ${ }^{19}$ Tennessee Department of Health; ${ }^{20}$ Missouri Department of Health and Senior Services; ${ }^{21}$ Kansas Department of Health and Environment; ${ }^{22}$ Ohio Department of Health; ${ }^{23}$ Iowa Department of Public Health; ${ }^{24}$ Delaware Department of Health and Social Services.

All authors have completed and submitted the International Committee of Medical Journal Editors form for disclosure of potential conflicts of interest. No potential conflicts of interest were disclosed.

\section{References}

1. Bureau of Labor Statistics. May 2019 national industry-specific occupational employment and wage estimates, NAICS 311600_-animal slaughtering and processing. Washington, DC: US Department of Labor, Bureau of Labor Statistics; 2019. https://www.bls.gov/oes/current/ naics4_311600.htm

2. CDC. Social distancing, quarantine, and isolation. Atlanta, GA: US Department of Health and Human Services, CDC; 2020. https://www. cdc.gov/coronavirus/2019-ncov/prevent-getting-sick/social-distancing. html

3. Wei WE, Li Z, Chiew CJ, Yong SE, Toh MP, Lee VJ. Presymptomatic transmission of SARS-CoV-2 - Singapore, January 23-March 16, 2020. MMWR Morb Mortal Wkly Rep 2020;69:411-5. http://dx.doi. org/10.15585/mmwr.mm6914e1

4. CDC. Meat and poultry processing workers and employers. Atlanta, GA: US Department of Health and Human Services, CDC; 2020. https:// www.cdc.gov/coronavirus/2019-ncov/community/organizations/meatpoultry-processing-workers-employers.html

5. McMichael TM, Clark S, Pogosjans S, et al.; Public Health - Seattle \& King County; EvergreenHealth; CDC COVID-19 Investigation Team. COVID-19 in a long-term care facility-King County, Washington, February 27-March 9, 2020. MMWR Morb Mortal Wkly Rep 2020;69:339-42. https://doi.org/10.15585/mmwr.mm6912e1

6. Heinzerling A, Stuckey MJ, Scheuer T, et al. Transmission of COVID-19 to health care personnel during exposures to a hospitalized patientSolano County, California, February 2020. MMWR Morb Mortal Wkly Rep 2020;69:472-6. https://dx.doi.org/10.15585/mmwr.mm6915e5

7. Akiyama MJ, Spaulding AC, Rich JD. Flattening the curve for incarcerated populations-Covid-19 in jails and prisons. N Engl J Med. Epub Apr 2, 2020. https://dx.doi.org/10.1056/NEJMp2005687

8. Mosites E, Parker EM, Clarke KE, et al. Assessment of SARS-CoV-2 infection prevalence in homeless shelters-four U.S. cities, March 27April 15, 2020. MMWR Morb Mortal Wkly Rep. 2020. Epub April 22, 2020. https://www.cdc.gov/mmwr/volumes/69/wr/mm6917e1. htm?s_cid=mm6917e1_w

9. Shaw KA, Szablewski CM, Kellner S, Kornegay L, Bair P, Brennan S, et al. Psittacosis outbreak among workers at chicken slaughter plants, Virginia and Georgia, USA, 2018. Emerg Infect Dis 2019;25:2143-5. https://dx.doi.org/10.3201/eid2511.190703 